\title{
Health and condition of Pacific herring Clupea pallasi from Prince William Sound, Alaska, 1994
}

\author{
Ralph A. Elston ${ }^{1, *}$, Ann S. Drum ${ }^{2}$, Walter H. Pearson ${ }^{2}$, Keith Parker ${ }^{3}$ \\ ${ }^{1}$ Aqua Technics Inc., PO Box 687, Carlsborg, Washington 98324, USA \\ ${ }^{2}$ Battelle Marine Sciences Laboratory, 1529 West Sequim Bay Road, Sequim, Washington 98382, USA \\ ${ }^{3}$ Data Analysis Group, 5100 Cherry Creek Road, PO Box 128, Cloverdale, California 95425, USA
}

\begin{abstract}
This study determined baseline health and condition values of Pacific herring Clupea pallasi in 1994 in Prince William Sound (PWS), Alaska. In April 1994, 134 herring were collected from 3 spawning sites in PWS, including a sequential sampling from 1 site. For each herring, morphometric characteristics, sex and presence of gross external and internal lesions were documented, and samples were processed for aging, virological, bacteriological and histological analysis. The study did not reveal trends in herring health and condition in 1994 that could reasonably be attributed to the 'Exxon Valdez' oil spill in 1989. No viruses or pathogenic bacteria were detected, but herring worms, a coccidian parasite and a systemic and virulent fungal infection were found in the herring. The degree of vacuolation in liver cells, previously thought to indicate exposure of fish to oil, varied significantly with the stage of reproductive development of the herring. Similarly, the liver melanomacrophage index, also believed to be correlated with environmental toxicant exposures, varied significantly among sample locations and with collection date. In this study, significant differences in age distribution of spawning herring populations occur in close geographic proximity and collection time intervals in PWS. Based on our results, the use of condition factor, disease and indices of liver function to indicate pollutant exposure are likely to be invalid unless other factors unrelated to pollutant exposure are taken into account, such as reproductive stage of the herring, spawning behavior and location, age of herring and collection date. Thus, we conclude that various hypotheses advanced regarding impacts of the 'Exxon Valdez' oil spill as well as other cases of environmental contamination cannot be supported without rigorous statistical evaluation of natural variations in indices of fish health and condition.
\end{abstract}

KEY WORDS: Pacific herring · Health · Condition - Diseases · Prince William Sound - Environmental impact 'Exxon Valdez' oil spill

\section{INTRODUCTION}

Pacific herring Clupea pallasi represent an important commercial fishery in the eastern North Pacific. Annual yields have historically ranged from 1000 to 17000 tons in Prince William Sound (PWS), Alaska (Brady et al. 1991). Subsequent to the March 1989 'Exxon Valdez' oil spill in PWS, there was general concern about the potential for direct, indirect, delayed or residual effects of the oil spill on natural populations of fish, including Pacific herring, although only about $4 \%$ of the known herring spawning areas were oiled by

•E-mail: relston@olympus.net the spill (Pearson et al. 1995). The fishery was closed for the entire 1989 season. In the 3 yr immediately after the oil spill, there were record-high biomass returns and harvests of herring in PWS. Returns of herring to PWS spawning grounds in 1993 were dramatically below projected levels, but were sufficient to support a reduced herring harvest. In 1994 and 1995, herring returns continued to decline, and the fishery was closed.

Because the spring herring fisheries are for roe, the harvest occurs only during herring spawning season and is concentrated in known spawning areas. Herring are known to return to traditional spawning sites, but unlike salmon, their site fidelity is not precise (that is, there is no evidence that herring 'home' to their site of 
origin). Further, there are occasional abrupt shifts in spawning sites. During most of the 1980s, spawning was distributed widely over PWS, including a high concentration in the north and northeast areas, the Naked Island archipelago and Montague Island, but not including Knight Island (Brady et al. 1991, Bienert \& Pearson 1993). Spawning in 1993 and 1994 was restricted predominantly to Montague Island (Bienert 1994). Of the mile-days of milt observed by Bienert (1994), 80\% was seen at Montague Island.

Various hypotheses could be considered to explain the 1993 and 1994 population decline, including poor health and condition of the spawning herring, natural population cycles and reduced food availability, as well as other factors (Pearson et al. 1996). The hypothesis that the 'Exxon Valdez' oil spill was a causal factor in the reduction, mediated through indirect and delayed mechanisms resulting in the expression of infectious diseases in the herring, was suggested by the declining returns in 1993 and 1994 and by the subsequent detection of viral hemorrhagic septicemia virus (VHSV) in PWS herring (Meyers et al. 1994). Monitoring by the Alaska Department of Fish and Game in 1993 and 1994 showed the presence of hyperemic lesions on the body surface of herring, which could have been caused by VHSV (Meyers et al. 1994).

This study was undertaken to make an initial evaluation of health and condition of herring from 3 of the known spawning locations in PWS in 1994. Our objectives were to establish a valid and needed baseline of the health and condition of these herring populations, including numerical variability in measured parameters; to evaluate year class differences in some of the health and condition parameters in herring populations; to evaluate the role of infectious diseases in herring declines; and to determine what reasonable hypotheses could be advanced based on these data.

\section{MATERIALS AND METHODS}

Sample collection. The herring for this study were collected in the vicinity of Montague Island, Prince William Sound, Alaska (Figs. 1 \& 2). Fish were collected from Rocky Bay (RB1) on April 12, 1994, and from Stockdale Harbor (SH) and Port Chalmers (PC) on April 13, 1994. Herring were also collected from Rocky Bay (RB2) on April 24, 1994. The fish were collected by Alaska Department of Fish and Game personnel, placed on ice, and were transported by air within approximately $24 \mathrm{~h}$ of collection to the Battelle Marine Sciences Laboratory (MSL) in Sequim, Washington.

The sample sites were not among the PWS locations that received moderate or heavy oil coating in 1989 from the 'Exxon Valdez' spill. The Rocky Bay site re- ceived a very light amount of oil, whereas Stockdale Harbor and Port Chalmers were generally considered to have been completely unoiled. The last oil surveys carried out in 1992 as followup to the spill revealed no evidence of oil at any of the 3 sites (Neff et al. 1995).

Sample processing. At processing, each fish was assigned a unique sample tracking number. Fish were weighed, measured for standard length and sampled for scales to determine age. Each fish was examined for external lesions and parasites; tissues were collected from external lesions, and a section of skin and skeletal muscle was sampled for histological processing.

The visceral and pericardial cavities of the fish were opened and examined. The number of herring worms was estimated. Kidney and spleen samples were collected for virological testing (Thoesen 1994). The kidney was sampled for bacteriological culture, histological processing and impression smears. After weighing, a small amount of liver tissue was taken for histological processing, and the remaining tissue was frozen at approximately $-80^{\circ} \mathrm{C}$. The sex and reproductive condition of the fish were recorded from visual observations of the gonadal tissue. The gonadal tissue was weighed, subsampled for histological processing, and roe was frozen at approximately $-80^{\circ} \mathrm{C}$. The stomach was examined for the presence or absence of food. Visceral organs and remaining tissues of the whole fish were preserved and stored in Davidson's fixative.

Virological processing and evaluation. Kidney and spleen samples were processed for virological analysis within $72 \mathrm{~h}$ of collection (Thoesen 1994). Kidney and spleen tissue samples from 60 individual fish were combined, homogenized, clarified and inoculated onto epithelioma papillosum cyprini (EPC) cell cultures in a 6-log dilution series, using standard virological procedures (Meyers et al. 1992). The cell cultures were incubated in a $\mathrm{CO}_{2}$ incubator at approximately $15^{\circ} \mathrm{C}$ and examined for cytopathic effect (CPE) for a minimum of $2 \mathrm{wk}$ post inoculation. Following this incubation period, cell culture supernatant from all $10^{-1}$ dilutions and from additional dilutions showing possible CPE were inoculated onto fresh EPC cell cultures and were observed for a minimum of an additional $2 \mathrm{wk}$.

Kidney and blood smears were fixed in methanol and stained with Diff-Quick (Baxter Healthcare Corp., Miami, FL, USA). These preparations were evaluated for the presence of inclusion bodies in the erythrocytes, which would suggest the presence of viral erythrocytic necrosis (VEN) infection, and other abnormal structures (Meyers et al. 1986). Using a $40 \times$ objective lens, at least 30 microscopic fields were examined. Bacteriological swabs from the kidneys were plated onto tryptic soy agar incubated aerobically at about $20^{\circ} \mathrm{C}$. These were examined for growth at 48 and 96 h. 
Histology. All samples for histological processing were fixed in Davidson's fixative, processed and stained with Harris' hematoxylin and eosin ( $H \& E$ ) using typical methods as described by Luna (1968). Only the histological results from organs used in numerical data analyses are reported in this paper. The following quantitative measurements were made on the H \& E stained materials as appropriate, essentially following the methods of Haensly et al. (1982): (a) mean concentration of macrophage centers per unit area of liver (10 fields examined with $20 \times$ objective lens magnification); (b) degree of hepatocellular vacuolation in the liver using an arbitrary scale $(0,1,2,3)$.

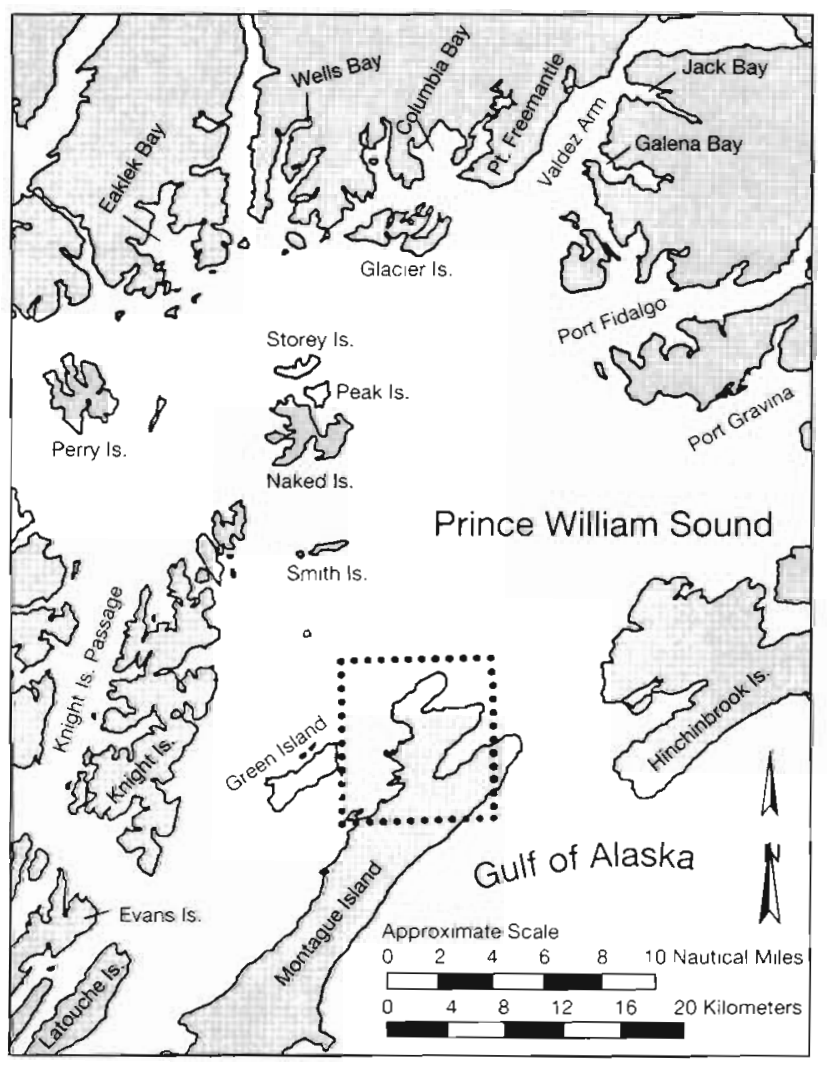

\section{$\Lambda$}

Fig. 1. Prince William Sound, Alaska. Sample sites are located within dotted-box area of Montague Island (see Fig. 2 for detail of north-northwest Montague Island)

Fig. 2. North-northwest Montague Island region. Sampling areas were Rocky Bay, Stockdale Harbor, and Port Chalmers
The level of development of reproductive structures was evaluated histologically. Five stages of reproductive structure development were assigned to individual herring: (1) no detectable development and sex indeterminate, (2) developing reproductive follicle, (3) mature reproductive follicle, (4) post-spawning reproductive follicle and (5) resorbing reproductive follicle.

Goussia clupearum infections within organs were rated as low, moderate or heavy, generating a numerical value of 1,2 or 3 , respectively, for each infected organ. In a small number of fish, multiple organs were infected with Goussia sp. After the prevalence was determined and the intensity of the infection within an organ was rated, a Goussia sp. severity index was generated for each fish by summing the intensity ratings of the infected organs. The severity index ranged from 0 to 5 .

Ichthyophonus hoferi infections within organs were rated as low, moderate and heavy, generating a numerical value of 1,2 or 3 , respectively, for each infected organ. After the prevalence was determined and the intensity of the infection within an organ was rated, an Ichthyophonus sp. severity index was generated for each fish by summing the intensity ratings of all the infected organs. The severity index ranged from 0 to 9 . 
Condition indices. The condition factor (CF) of the herring was calculated as $100 \times[$ weight $(\mathrm{mg}) /$ length $(\mathrm{mm})]^{3}$. The gonosomatic index (GSI) was expressed as gonad weight per whole fish weight. The hepatosomatic (liver) index (HSI) was calculated as liver weight per weight of whole fish.

Statistical analysis. The 4 sample groups collected in mid-and late April 1994 were tested for differences and trends in health and condition. The major effect categories tested were sampling locations, collection dates, year class, sex and reproductive stage. Three sets of analyses were run to estimate and test for differences in prevalence of indices. First, all 134 fish were used to estimate prevalence of indices by major effect categories, and to estimate mean weight, length and CF. Second, the dominant year classes $(1988,1989$ and 1990) were tested for differences. Third, the 1990 year class, which was adequately present for statistical analysis in the 4 collections, was tested for effects of sex, location and reproductive stage.

Physical, reproductive, and significant health and condition indices that were dependent variables in the analysis consisted of the following: (1) fin lesion prevalence, (2) number of fins with lesions, (3) skin lesion prevalence, (4) total surface area $\left(\mathrm{mm}^{2}\right)$ the skin lesions covered, (5) condition factor, (6) gonosomatic index, (7) liver hepatosomatic index, (8) liver hepatocellular vacuolation index, (9) liver melanomacrophage index, (10) reproductive stage, (11) Ichthyophonus sp. prevalence, (12) Ichthyophonus sp. intensity, (13) Ichthyophonus sp. severity, (14) Goussia sp. prevalence, (15) Goussia sp. intensity, (16) Goussia sp. severity, (17) standard length and (18) total body weight.

Two types of statistical analyses were used to assess effects depending on whether the dependant variable was continuous or categorical. For continuous variables (e.g. condition factor) analysis of variance (ANOVA) was used. For categorical variables (e.g. fin lesion prevalence) the LogLikelihood $\chi^{2}$ (Fienberg 1980) analogue to ANOVA was used. P-values for dependent variables in results are listed as either ANOVA for continuous or $\chi^{2}$ for categorical. Sample sizes (n) varied among tests but were generally large with median $\mathrm{n}=40$. For most tests there was at least $80 \%$ power for detecting a $50 \%$ change (Cohen 1988).

\section{RESULTS}

\section{Necropsy}

Grossly observable lesions consisted primarily of hyperemia at the fin bases and on the body surface. Of the 134 fish examined $57 \%$ had such lesions, although in most cases, the reddish discoloration on the body
Table 1 Clupea pallasi. Summary of external lesions and herring worms Anasakis sp. in herring collected from Prince William Sound, Alaska, in 1994

\begin{tabular}{|lrcc|}
\hline Sample date & $\mathrm{n}$ & External lesions $^{\alpha}$ & Herring worms \\
\hline April 12 \& 13 & 99 & $56 \%$ & $97 \%$ \\
April 24 & 35 & $63 \%$ & $100 \%$ \\
${ }^{\circ}$ Skin and fin lesions & & \\
\hline
\end{tabular}

surface was not prominent (Table 1). In some cases, the scales were raised, but no ulceration was observed.

Nematodes, or herring worms (Anasakis sp.), were observed in the visceral cavity of $97 \%$ of the fish collected on April 12 and 1.3 and in $100 \%$ of the fish collected on April 24 (Table 1). There was no statistically significant association of nematode prevalence with collection site, year class, collection date, sex or reproductive stage.

Multiple white nodular lesions up to $0.5 \mathrm{~mm}$ in diameter were observed on the livers of 3 fish and on the heart of 1 fish collected from Port Chalmers on April 13. Similar white multifocal lesions were observed on the livers of 2 fish and on the liver, heart and visceral cavity of 1 fish collected from Rocky Bay on April 24. These lesions were later determined to result from heavy Ichthyophonus sp. infections.

\section{Impression smears, bacteriology and virology}

Examination of impression smears did not reveal cytoplasmic inclusion bodies consistent with VEN disease in any of the herring examined (Meyers et al. 1986). All of the bacteriological cultures of kidneys from 134 fish were negative for uniform colony growth. None of the virological cultures of kidney and spleen samples showed cytopathic effect on primary inoculated cultures or subcultures.

\section{Age}

The age of 123 herring ranged from 2 to 8 yr $(1992$ through 1986 year classes) and the majority were 4,5 and 6 yr old fish, representing $36 \%, 24 \%$ and $24 \%$, respectively, of the total (Fig. 3). The age distribution of herring varied with sample location and date of collection.

Sample location. At Port Chalmers $75 \%$ of the fish collected were 3 or 4 yr old. At Stockdale Harbor $96 \%$ of the herring were 4, 5 or 6 yr old fish, with the 4 and 6 yr olds each representing $37 \%$ of the total. In the Rocky Bay 1 sample $77 \%$ of the fish were 5 or 6 yr old fish, with the 6 yr olds representing $43 \%$ of the collection. 

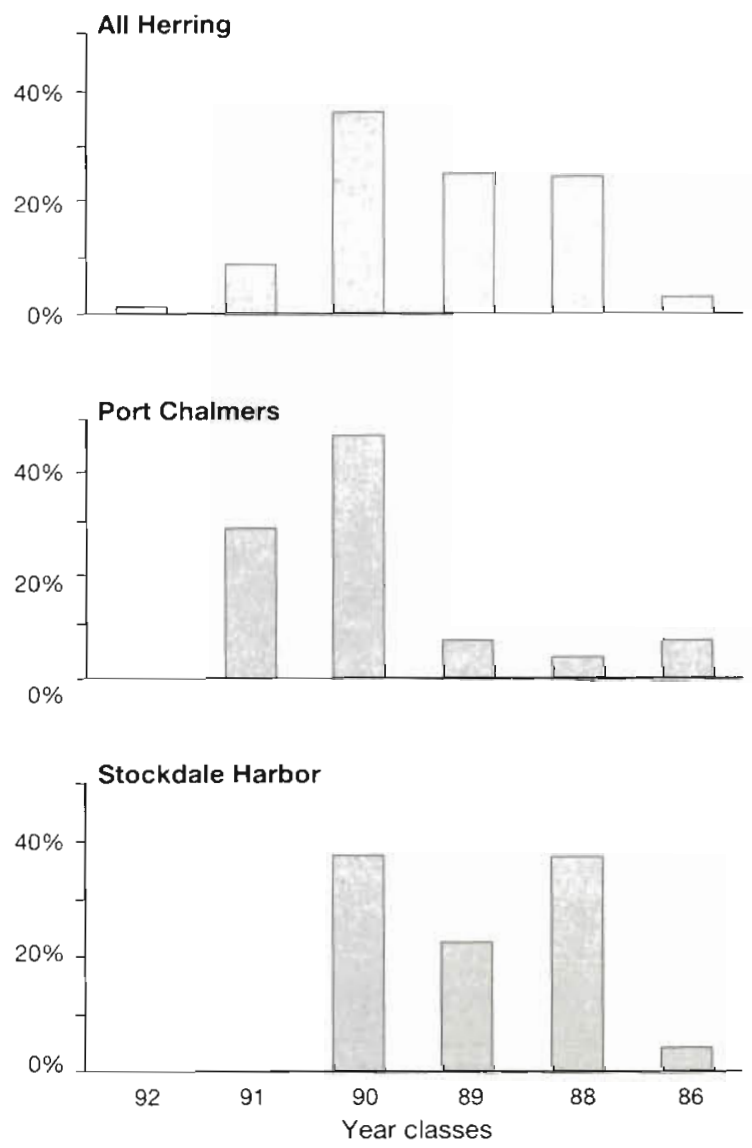
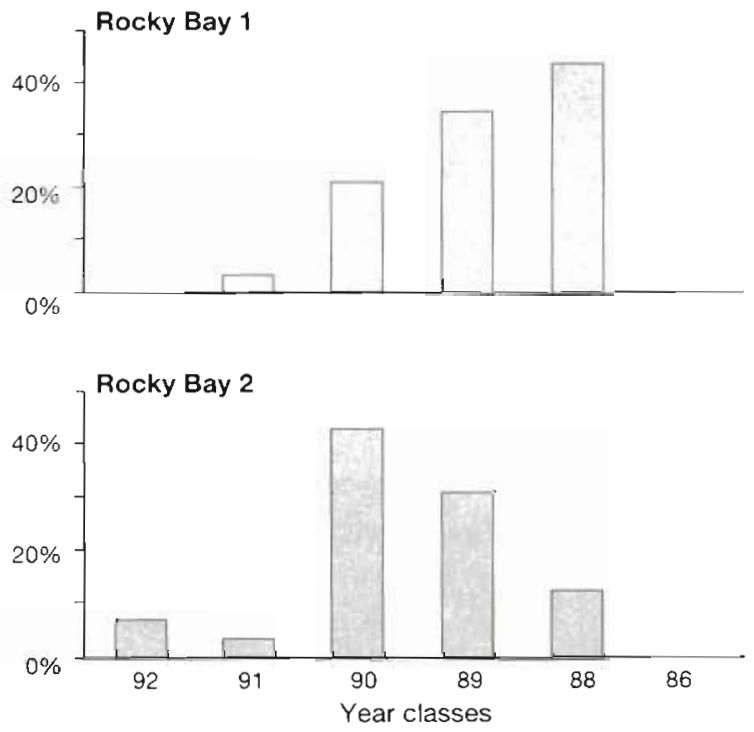

Fig. 3. Clupea pallasi. Age distribution of all fish and of individual collections ( $\mathrm{PC}, \mathrm{SH}, \mathrm{RB} 1, \mathrm{RB} 2$ )
Collection date. In the Rocky Bay 2 group, collected approximately 2 wk after Rocky Bay 1 samples, $72 \%$ of the herring were 4 and 5 yr old fish, and of these, 4 yr old fish predominated.

\section{Length, weight and condition factor}

The length, weight and CF of 123 herring are summarized by age in Table 2 . As anticipated, the average weight, length and $\mathrm{CF}$ of the fish tended to increase with age and Table 3 summarizes the length, weight and condition factors of 4 yr old fish only by sampling location. These indices vary among members of this year class with geographic location. The average condition factors of 134 herring by collection date, location and year class are summarized in Table 4. Statistical analysis of weight and $C F$ revealed significant differences by sample location $\left({ }^{L}\right)$, collection date $\left({ }^{\top}\right)$ and age $\left({ }^{A}\right)$.
Table 2. Clupea pallasi. Summary of length, weight and condition factor $[C F$; expressed as (weight, $\mathrm{mg} /$ length, $\mathrm{mm})^{3} \times 100$ ] by age of herring collected from Prince William Sound, Alaska, in 1994

\begin{tabular}{|c|c|c|c|c|c|c|}
\hline $\begin{array}{l}\text { Year } \\
\text { class }\end{array}$ & Age & $\mathrm{n}$ & & $\begin{array}{l}\text { Length } \\
(\mathrm{cm})\end{array}$ & $\begin{array}{l}\text { Weight } \\
\text { (g) }\end{array}$ & $\mathrm{CF}$ \\
\hline 1992 & 2 & 1 & $\begin{array}{l}\text { Mean } \\
\text { SD } \\
\text { Range }\end{array}$ & 17.0 & 50.1 & 1.02 \\
\hline 1991 & 3 & 10 & $\begin{array}{l}\text { Mean } \\
\text { SD } \\
\text { Range }\end{array}$ & $\begin{array}{c}20.4 \\
1.6 \\
(18.5 \text { to } 23.5)\end{array}$ & $\begin{array}{c}77.7 \\
17.8 \\
(60.0 \text { to } 121.9)\end{array}$ & $\begin{array}{c}0.91 \\
0.08 \\
(0.71 \text { to } 1.02)\end{array}$ \\
\hline 1990 & 4 & 44 & $\begin{array}{l}\text { Mean } \\
\text { SD } \\
\text { Range }\end{array}$ & $\begin{array}{c}21.3 \\
1.5 \\
(19.0 \text { to } 25.5)\end{array}$ & $\begin{array}{c}92.7 \\
23.1 \\
(60.8 \text { to } 162.6)\end{array}$ & $\begin{array}{c}0.94 \\
0.09 \\
(0.81 \text { to } 1.11)\end{array}$ \\
\hline 1989 & 5 & 30 & $\begin{array}{l}\text { Mean } \\
\text { SD } \\
\text { Range }\end{array}$ & $\begin{array}{c}23.0 \\
1.2 \\
(20.0 \text { to } 25.5)\end{array}$ & $\begin{array}{c}117.8 \\
19.8 \\
(74.0 \text { to } 160.6)\end{array}$ & $\begin{array}{c}0.96 \\
0.09 \\
(0.72 \text { to } 1.13)\end{array}$ \\
\hline 1988 & 6 & 30 & $\begin{array}{l}\text { Mean } \\
\text { SD } \\
\text { Range }\end{array}$ & $\begin{array}{c}23.2 \\
1.5 \\
\{19.5 \text { to } 27.5\}\end{array}$ & $\begin{array}{c}129.4 \\
24.8 \\
(74.4 \text { to } 211.1)\end{array}$ & $\begin{array}{c}1.02 \\
0.07 \\
(0.85 \text { to } 1.20)\end{array}$ \\
\hline 1987 & 7 & 5 & $\begin{array}{l}\text { Mean } \\
\text { SD } \\
\text { Range }\end{array}$ & $\begin{array}{c}24.7 \\
0.2 \\
(24.5 \text { to } 25.0)\end{array}$ & $\begin{array}{c}146.6 \\
8.3 \\
(138.4 \text { to } 159.0)\end{array}$ & $\begin{array}{c}0.97 \\
0.04 \\
(0.92 \text { to } 1.03)\end{array}$ \\
\hline 1986 & 8 & 3 & $\begin{array}{l}\text { Mean } \\
\text { SD } \\
\text { Range }\end{array}$ & $\begin{array}{c}26.2 \\
0.8 \\
(25.5 \text { to } 27.0\}\end{array}$ & $\begin{array}{c}181.6 \\
16.1 \\
(170.8 \text { to } 200.1)\end{array}$ & $\begin{array}{c}1.01 \\
0.02 \\
(0.99 \text { to } 1.03)\end{array}$ \\
\hline
\end{tabular}


Table 3. Clupea pallasi. Summary of length, weight and condition factor $[C F$; expressed as (weight, $\mathrm{mg} /$ length, $\mathrm{mm}$ ) $^{3} \times 100$ ) of 4 yr old herring collected from Prince William Sound, Alaska, in 1994

\begin{tabular}{|c|c|c|c|c|c|}
\hline $\begin{array}{l}\text { Collection } \\
\text { site }\end{array}$ & n & & $\begin{array}{l}\text { Length } \\
(\mathrm{cm})\end{array}$ & $\begin{array}{l}\text { Weight } \\
\text { (g) }\end{array}$ & $C F$ \\
\hline All & 44 & $\begin{array}{l}\text { Mean } \\
\text { SD } \\
\text { Range }\end{array}$ & $\begin{array}{c}21.3 \\
1.5 \\
(19.0 \text { to } 25.5)\end{array}$ & $\begin{array}{c}92.7 \\
23.1 \\
(60.8 \text { to } 162.6)\end{array}$ & $\begin{array}{c}0.94 \\
0.09 \\
(0.81 \text { to } 1.11)\end{array}$ \\
\hline $\begin{array}{l}\text { Port } \\
\text { Chalmers }\end{array}$ & 13 & $\begin{array}{l}\text { Mean } \\
\text { SD } \\
\text { Range }\end{array}$ & $\begin{array}{c}20.4 \\
0.7 \\
(19.0 \text { to } 21.5)\end{array}$ & $\begin{array}{c}76.2^{\mathrm{a} L t} \\
7.8 \\
(62.8 \text { to } 89.6)\end{array}$ & $\begin{array}{c}0.89^{a L 2} \\
0.06 \\
(0.81 \text { to } 1.00)\end{array}$ \\
\hline $\begin{array}{l}\text { Stockdale } \\
\text { Harbor }\end{array}$ & 10 & $\begin{array}{l}\text { Mean } \\
\text { SD } \\
\text { Range }\end{array}$ & $\begin{array}{c}21.8 \\
1.5 \\
(20.0 \text { to } 24.5)\end{array}$ & $\begin{array}{c}102.9^{\mathrm{a} L 1} \\
19.2 \\
(73.4 \text { to } 134.4)\end{array}$ & $\begin{array}{c}0.98 \\
0.08 \\
(0.87 \text { to } 1.09)\end{array}$ \\
\hline Rocky Bay 1 & 7 & $\begin{array}{l}\text { Mean } \\
\text { SD } \\
\text { Range }\end{array}$ & $\begin{array}{c}21.7 \\
1.0 \\
(20.2 \text { to } 23.5)\end{array}$ & $\begin{array}{c}103.7^{\mathrm{a} L 1} \\
21.6 \\
(69.1 \text { to } 138.7)\end{array}$ & $\begin{array}{c}1.00^{0 \mathrm{~L} 2 \mathrm{~T}} \\
009 \\
(0.84 \text { to } 1.07)\end{array}$ \\
\hline Rocky Bay 2 & 14 & $\begin{array}{l}\text { Mean } \\
\text { SD } \\
\text { Range }\end{array}$ & $\begin{array}{c}21.6 \\
1.8 \\
(19.2 \text { to } 25.5)\end{array}$ & $\begin{array}{c}95.4 \\
28.6 \\
(60.8 \text { to }(162.6)\end{array}$ & $\begin{array}{c}0.92^{\mathrm{a} T} 1 \\
0.09 \\
(0.81 . \text { to } 1.11)\end{array}$ \\
\hline \multicolumn{6}{|c|}{$\begin{array}{l}\text { AMeans are significantly different: } \\
\text { L1 Location: The weight of fish collected at Port Chalmers is less than that of } \\
\text { fish collected from SH, RB1, and RB2 ( } 1 \text {-way ANOVA: } p<0.01 \text {, df }=43 \text { ) } \\
{ }^{\text {L2 }} \text { Location: The CF of fish collected at Port Chalmers is less than that of fish col- } \\
\text { lected at Rocky Bay } 1 \text { ( } 1 \text {-way ANOVA: } p<0.01 \text {, df }=43 \text {; Tukey-Kramer HSD) } \\
\text { T1 Time: The CF of fish from RB1 was greater than that of fish from RB2 } \\
\text { (collected at a } 10 \mathrm{~d} \text { interval) ( } 1 \text {-way ANOVA: } p<0.05 \text {; Tukey-Kramer) }\end{array}$} \\
\hline
\end{tabular}

Sample location. The predominant age class ( 4 yr old fish, 1990 year class) revealed statistically significant variation in weight and in CF by sample location (Table 3, ${ }^{\mathrm{L} 1}$ and ${ }^{\mathrm{L} 2}$ ). The average weight $(76 \pm 8 \mathrm{~g})$ of the Port Chalmers fish was significantly less than that of fish collected from Rocky Bay $1(104 \pm 22 \mathrm{~g})$. Stockdale Harbor $(103 \pm 19 \mathrm{~g})$ and Rocky Bay 2 (95 $\pm 29 \mathrm{~g})$. The fish collected from Port Chalmers not only had low body weight, but were also shorter than the herring collected from SH and RB1, but the average standard length was not significantly different among sites $(p=0.07)$. The CF of the 4 yr old fish from Port Chalners was significantly lower than that of the fish collected from Rocky Bay 1.

Collection date. The fish collected from the same location at a $12 \mathrm{~d}$ interval (RB1 and RB2) varied by location, and revealed a trend toward lower weight and CF (Table 3). The average

Table 4. Clupea pallasi. Summary of condition factor [CF; expressed as (weight, mg/length, $\mathrm{mm})^{3} \times 100$ ] of herring collected from Prince William Sound, Alaska, in 1994 by age, sampling location and collection date

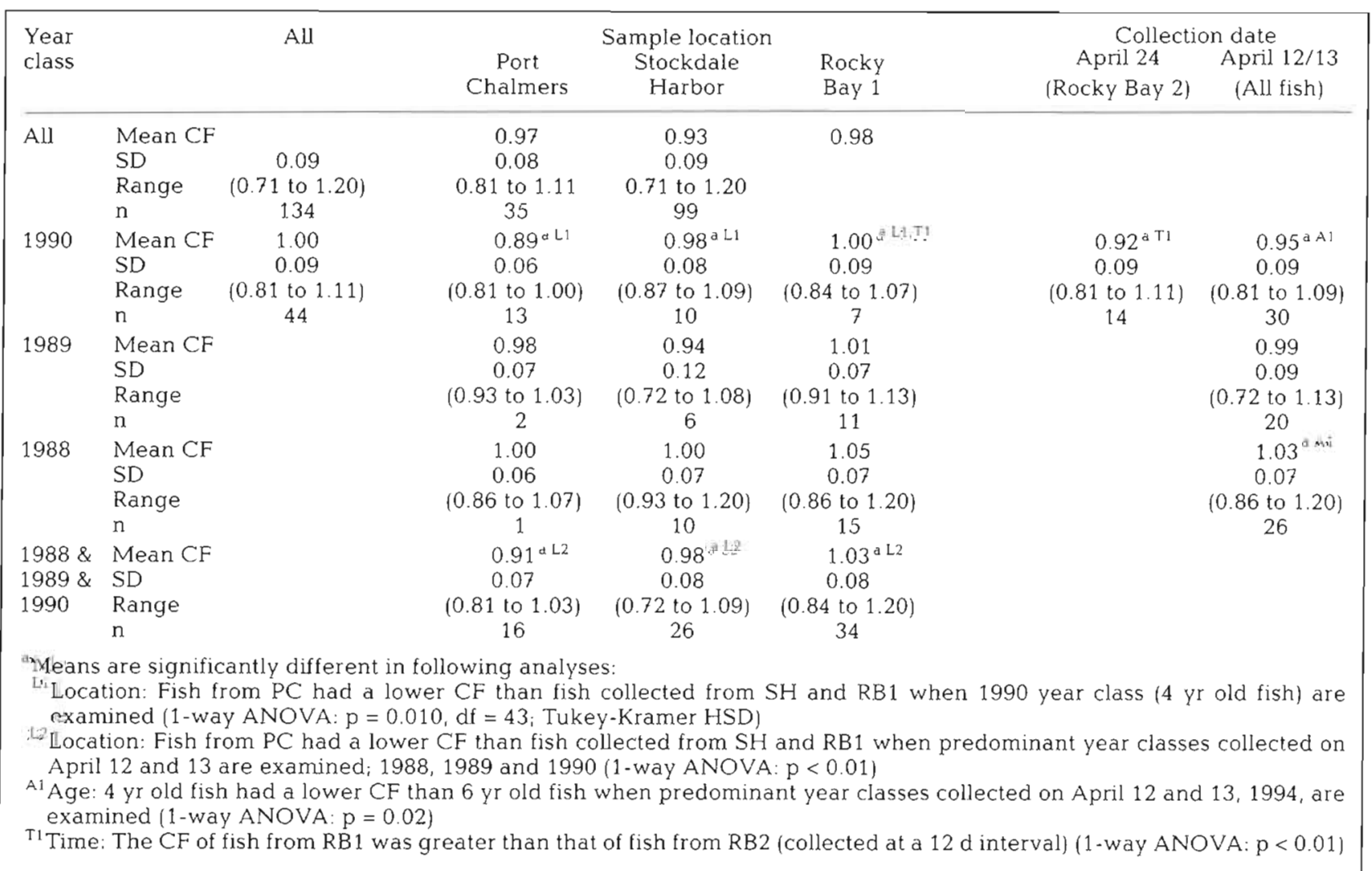


weight of the Rocky Bay 2 fish $(95 \mathrm{~g})$ was lower than that of the Rocky Bay 1 fish (104 g). However, the average lengths of the fish collected from Rocky Bay 1 and Rocky Bay 2 were similar (21.6 and $21.7 \mathrm{~cm}$, respectively). The lower weight of the fish at Rocky Bay 2 resulted in a statistically significant lower average CF (Table $3,{ }^{\mathrm{Tl}}$ ) for these fish (0.92) compared with the fish of a similar length from Rocky Bay 1 (1.00).

Year class. The CF of the 1990, 1989 and 1988 year class fish sampled on April 12 and 13 indicated a trend toward higher CF with increasing age $(0.95,0.99$ and 1.03 , respectively). Among the predominant year classes, the $4 \mathrm{yr}$ old fish had a statistically significant lower CF than the 6 yr olds (Table $4,{ }^{A 1}$ ).

\section{Sex}

Sample location. The fish in the Rocky Bay 1, Stockdale Harbor and Port Chalmers samples were $44 \%$, $43 \%$ and $47 \%$ female, respectively.

Collection date. Of the 99 fish collected on April 12 and $13,46 \%$ were female, and $54 \%$ were male. The fish collected on April 24 from Rocky Bay 2 were 29\% female and $71 \%$ male.

Year class. No trends or statistically significant differences related to year class were evident in the analysis.

\section{Reproductive and other condition indices}

Reproductive stage. Table 5 summarizes the reproductive stage of 133 herring, which ranged from developing (Stage 2) through spawned-out condition (Stages 4 and 5). Statistical analysis revealed significant differences in the reproductive stage of the fish by sample location and collection date. No significant differences were found in reproductive stage among the predominant 4,5 and 6 yr old fish.

Sample location: Among the 3 locations sampled in mid-April, $33 \%, 27 \%$ and $20 \%$ of the fish at Port Chalmers, Rocky Bay 1, and Stockdale Harbor, respectively, were in Stage 2 of reproductive development.

Collection date: All spawned-out fish were from Rocky Bay 2. The reproductive state of the 1990 year class fish collected from Rocky Bay 2 was significantly different from that of the fish collected at each of the 3 locations on April 12 and 13 (Table 5, ${ }^{\mathrm{Tl}}$ ).

Condition factor and reproductive stage: The average CF of 133 herring by reproductive stage is summarized in Table 6 . A trend toward lower CF as the fish progressed through the reproductive cycle was evi- dent in these herring. The CF of the spawned-out fish was lower than that of the fish that were developing or were reproductively mature. Although limited by the small number of spawned-out fish in the predominant 1990 year class, the CF of the 4 yr old fish was tested for reproductive stage effect. Spawned-out fish showed a trend toward lower CF than the developing and mature fish, but the results were not statistically significant ( 1 -way analysis of variance, ANOVA: $p=0.26$, $\mathrm{df}=42$ )

Gonosomatic index. The results of statistical analysis of the GSI of all fish, fish making up the 1990 year class and fish of the predominant year classes (1988, 1989 and 1990) by sample location is presented in Table 7 .

Sample location: The average GSI of all fish collected from Port Chalmers was significantly lower than those of fish collected from Rocky Bay 1 and Stockdale Harbor (Table 7, L1). The average GSI of the predominant 1988, 1989 and 1990 year class fish from Port Chalmers was significantly lower than those of the fish from Rocky Bay 1 and Stockdale Harbor (Table 7, L2).

Collection date: The average GSIs of fish collected from Rocky Bay on April 24 (RB2) were significantly lower than those of the fish collected from Rocky Bay on April 12 (Table $7{ }^{\mathrm{Tl}}$ ).

Table 6. Clupea pallasi. Summary of reproductive stage and condition factor [CF; expressed as (weight, mg/length, $\mathrm{mm})^{3} \times 100$ ] of herring collected from Prince William Sound, Alaska, in 1994

\begin{tabular}{|lccc|}
\hline CF & \multicolumn{3}{c|}{ Reproductive stage } \\
& Developing & Mature & Spawned-out \\
\hline Mean & 1.00 & 0.97 & 0.88 \\
SD & 0.08 & 0.09 & 0.04 \\
Range & $(0.84$ to 1.13$)$ & $(0.71$ to 1.20$)$ & $(0.83$ to 0.92$)$ \\
n & 27 & 96 & 10 \\
\hline
\end{tabular}


Table 7. Clupea pallasi. Summary of gonosomatic indices [GSI expressed as gonad wt (g) per fish wt (g)] of herring collected from Prince William Sound, Alaska, in 1994 by age, collection date, and sampling location

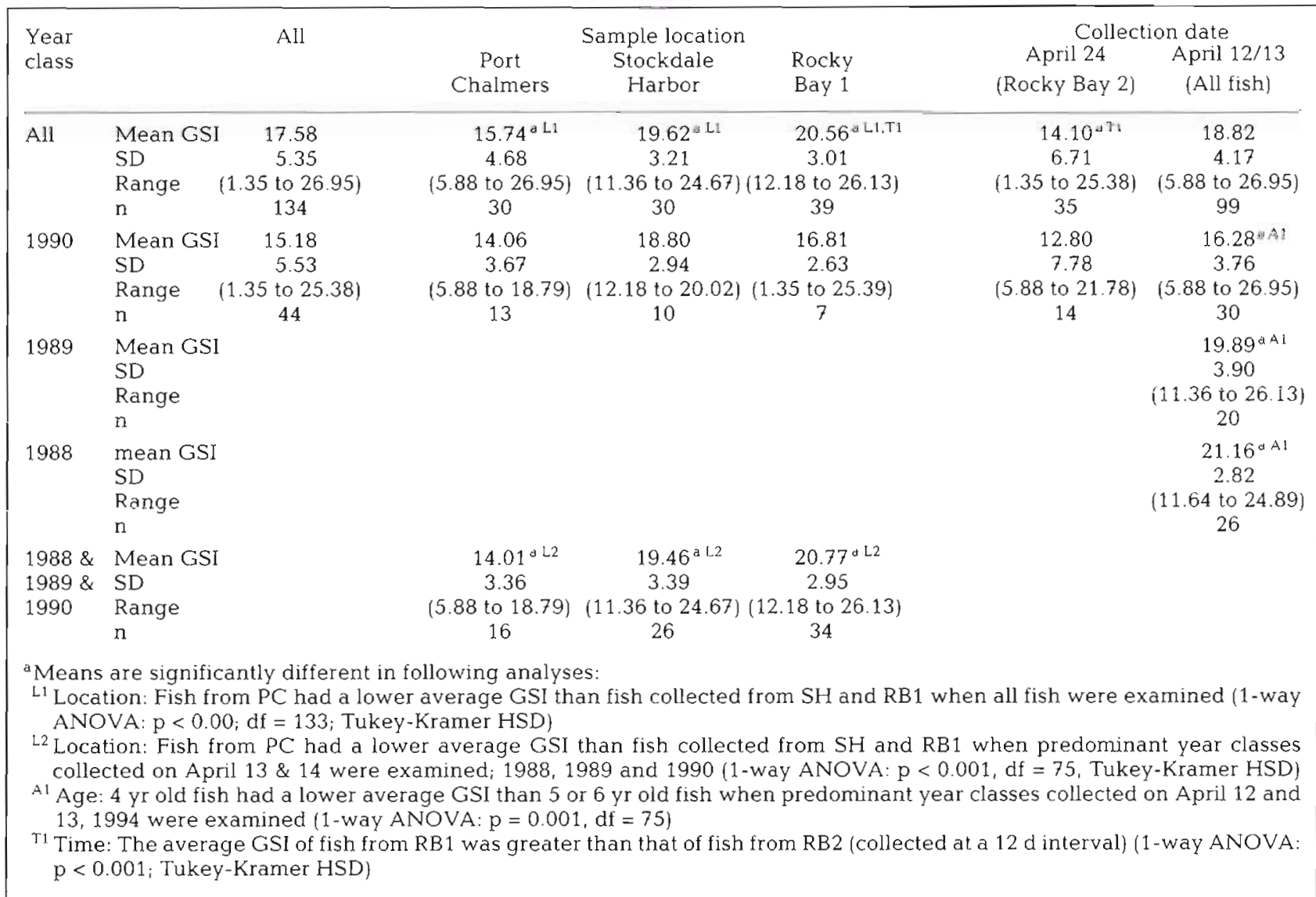

Year class: The average GSI of the 1990 year class fish was significantly lower than those of the older 1989 and 1988 year class fish (Table $7,{ }^{A 1}$ ).

Hepatosomatic index. The HSI, calculated as liver weight per weight of whole fish, was computed for 134 herring. Statistical analysis of the 1990 year class fish collected from all locations revealed significant correlations between the HSI and the location, sex and year class of the fish.

Sample location: The 1990 year class fish collected from Port Chalmers had a significantly higher HSI $(1.41 \pm 0.63)$ than that of the same year class fish collected from Rocky Bay $1(0.80 \pm 0.23)$, Rocky Bay 2 $(1.03 \pm 0.19)$ and Stockdale Harbor $(0.90 \pm 0.17)$ ( 1 -way ANOVA: $\mathrm{p}=0.0035, \mathrm{df}=40 ;$ Hsu's MCB LSD -0.07 to $-0.23,0.06$ to 0.24$)$. The analysis of the 1988,1989 and 1990 year class data showed that the fish from Port Chalmers had a significantly higher $(\mathrm{p}<0.001)$ average HSI $(1.30 \pm 0.61)$ than that of the fish from Rocky Bay $1(0.82 \pm 0.17)$ and Stockdale Harbor $(0.95 \pm 0.20)$.

Sex: The male fish in the 1990 year class had a significantly lower average HSI than that of the female 1990 year class fish ( 1 -way ANOVA: $p=0.0003, \mathrm{df}=43$ ).
Reproductive stage: Among the 1990 year class, the trend was toward a higher average HSI index for the mature fish $(1.11 \pm 0.44)$ in comparison with that of the developing $(0.83 \pm 0.19)$ and the spawned-out fish $(0.98 \pm 0.20)$.

\section{Gross and microscopic lesions}

Fin and skin lesions. Sixty-eight grossly observed fin and skin lesions were collected from 51 fish and examined histologically. The examination revealed diffuse epidermal and dermal macrophage infiltration, congestion of small blood vessels, hemorrhages and foci of necrotic cells.

Fin lesions. The prevalence of fin lesions for 134 fish is summarized in Table 8 . Of 134 fish, $49 \%$ had fin lesions, and the prevalence of fin lesions in the midand late April collections was $48 \%$ and $49 \%$, respectively. However, statistical analysis revealed that the prevalence of fin lesions varied significantly with sampling location when all fish, the predominant year classes collected on a single date and the predominant 
Table 8. Clupea pallasi. Prevalence of predominant histopathological lesions in herring collected from Prince William Sound, Alaska, in 1994

\begin{tabular}{|c|c|c|c|c|c|c|c|}
\hline Sample date & $\mathrm{n}$ & Ichthyophonus sp. & Goussia sp. & $\begin{array}{l}\text { Goussia sp. } \\
\text { associated }\end{array}$ & $\begin{array}{l}\text { Skin } \\
\text { lesion }\end{array}$ & $\begin{array}{l}\text { Fin } \\
\text { lesions }\end{array}$ & $\begin{array}{l}\text { No } \\
\text { lesions }\end{array}$ \\
\hline $\begin{array}{l}\text { All } \\
n\end{array}$ & 134 & $\begin{array}{c}18 \% \\
24\end{array}$ & $\begin{array}{c}49 \% \\
65\end{array}$ & $\begin{array}{c}13 \% \\
18\end{array}$ & $\begin{array}{c}36 \% \\
48\end{array}$ & $\begin{array}{c}49 \% \\
65\end{array}$ & $\begin{array}{c}19 \% \\
26\end{array}$ \\
\hline $\begin{array}{l}\text { April 12, } 13 \\
\mathrm{n}\end{array}$ & 99 & $\begin{array}{c}16 \% \\
16\end{array}$ & $\begin{array}{c}48 \% \\
48\end{array}$ & $\begin{array}{c}17 \% \\
17\end{array}$ & $\begin{array}{c}35 \% \\
34\end{array}$ & $\begin{array}{c}48 \% \\
48\end{array}$ & $\begin{array}{c}21 \% \\
21\end{array}$ \\
\hline $\begin{array}{l}\text { April } 24 \\
\mathrm{n}\end{array}$ & 35 & $\begin{array}{c}23 \% \\
8\end{array}$ & $\begin{array}{c}49 \% \\
17\end{array}$ & $\begin{array}{c}3 \% \\
1\end{array}$ & $\begin{array}{c}40 \% \\
14\end{array}$ & $\begin{array}{c}49 \% \\
17\end{array}$ & $\begin{array}{c}14 \% \\
5\end{array}$ \\
\hline
\end{tabular}

year class in all collections were analyzed. The prevalence of fin lesions did not vary significantly with collection date or among predominant year classes.

Sample location: The prevalence of fin lesions was higher in fish from Port Chalmers (80\%) and Rocky Bay $2(58 \%)$ than in fish collected from Stockdale Harbor (37\%) and Rocky Bay 1 (33\%). Within the predominant year classes collected on April 12 and 13, the prevalence of fin lesions was higher among fish from Port Chalmers than among fish from Stockdale Harbor or Rocky Bay 1 ( $p=0.001)$. The prevalence of fin lesions in the 1990 year class was significantly higher in fish collected from the Port Chalmers $(92 \%)$ and Rocky Bay $2(64 \%)$ locations than in fish from Stockdale Harbor $(20 \%)\left(p=0.003, \chi^{2}=13.84, d f=43\right.$; RB2 and $\mathrm{SH} \mathrm{p}=0.03, \chi^{2}=4.85, \mathrm{df}=23 ; \mathrm{PC}$ and $\mathrm{SH} \mathrm{p}=$ $0.0002, \chi^{2}=13.73, \mathrm{df}=22$ ). Further, more than $50 \%$ of the 1990 year class fish from Port Chalmers and Rocky Bay 2 had lesions on more than 3 fins, whereas 100\% of the fish from RB1 and SH had lesions on only 1 or 2 fins.

Skin lesions. The prevalence of skin lesions for 134 fish is summarized in Table 8 . The average prevalence of skin lesions for all fish, fish collected in the midApril sampling and fish collected in late April was $36 \%, 35 \%$ and $40 \%$, respectively. There were statistically significant differences in the total surface area covered with skin lesions by location and collection date. Lesion prevalence and affected surface area did not vary significantly with year class.

Sample location: The fish collected from Port Chaimers had significantly more average surface area covered with skin lesions on average $\left(6.3 \mathrm{~mm}^{2}\right)$ than those collected from Rocky Bay $1\left(2.3 \mathrm{~mm}^{2}\right)(\mathrm{p}<0.05, \mathrm{df}$ = 133; PC > RB1: $p<0.05$; Student's $t$-test: $t=0.10$ ).

Collection date: The average surface area covered with skin lesions was significantly larger on fish collected from Rocky Bay $2\left(7.0 \mathrm{~mm}^{2}\right)$ than on fish from Rocky Bay $1\left(2.3 \mathrm{~mm}^{2}\right)(\mathrm{p}<0.05, \mathrm{df}=133$; RB2 > RB1: $\mathrm{p}<0.05$; Student's $t$-test: $t=1.00)$.

Fin and skin lesions and condition factor: The CF of fish with either skin lesions, fin lesions, or skin and fin lesions was not lower than that of fish without external lesions when all fish (ANOVA: $p=0.28$, $d f=133$ ), the fish collected in mid-April ( $p=0.72, d f=97$ ), and the fish collected in late April ( $p=0.94, \mathrm{df}=33$ ) were tested.

Internal lesions. The principal lesions considered to represent significant changes in health status, disease processes or those conditions used in numerical analysis are reported here.

Goussia clupearum: G. clupearum, a coccidian parasite known to infect Pacific herring, was observed in the liver and occasionally in the pancreas and visceral connective tissues of some herring. G. clupearum infections consisted of individual spherical oocysts approximately $20 \mu \mathrm{m}$ in diameter, but more frequently, were aggregations of oocysts in the liver tissue (Fig. 4A). Some oocysts and oocyst aggregates were associated with accumulations of host inflammatory cells and with variable degrees of circumferential fibrosis and internal necrosis. Up to 4 sporocysts were observed within mature oocysts. G. clupearum sporocysts contain 2 sporozoites in an ovoid shell. The sporocyst shell wall in the genus Goussia is made up of 2 oval valves forming a distinctive suture line (Fig. 4A) (Dykova \& Lom 1981). Sporulated and unsporulated forms of $G$. clupearum were observed in $49 \%$ of the fish, and the prevalence in the fish collected in mid-April and late April was $48 \%$ and $49 \%$, respectively. The prevalence of low, moderate and heavy infections of $G$. clupearum in liver samples from all fish was $78 \%, 17 \%$ and $5 \%$, respectively.

In $13 \%$ of 132 livers examined, there were multifocal, lightly stained areas that were not well circumscribed, which contained necrotic hepatocytes, small dense granules and limited or no indication of cellular infiltration (Fig. 5A). The host inflammatory cells present within these areas were generally non-pigmented, and some contained small dense granules similar to those observed in unsporulated oocysts. Rarely, a few Goussia clupearum oocytes or pre-sporulated forms could be seen within these areas (Fig. 4B, C). These lesions appear to represent a host response to early or recovering G. clupearum infections. 


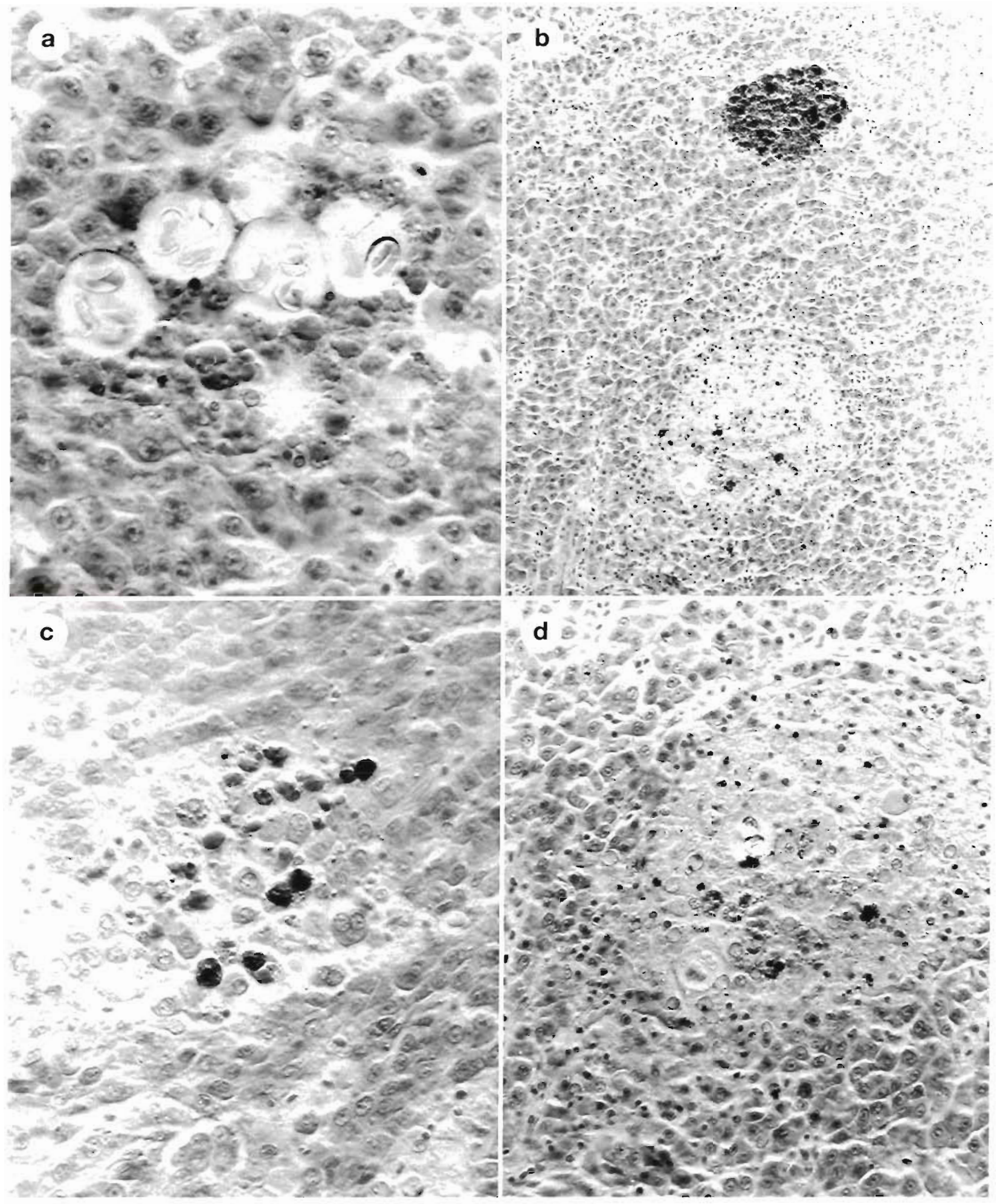

Fig. 4. Goussia clupearum in Clupea pallasi. (a) Sporulated oocysts ( $20 \mu \mathrm{m})$ of $G$. clupearum, each containing up to 4 sporocysts in herring liver tissue, $800 \times$. (b) G. clupearum associated lesion with oocysts and melanomacrophage center, 178×. (c) Magnified G. clupearum associated lesion in liver with oocysts, $800 \times$. (d) G. clupearum associated lesion in liver, $607 \times$ 


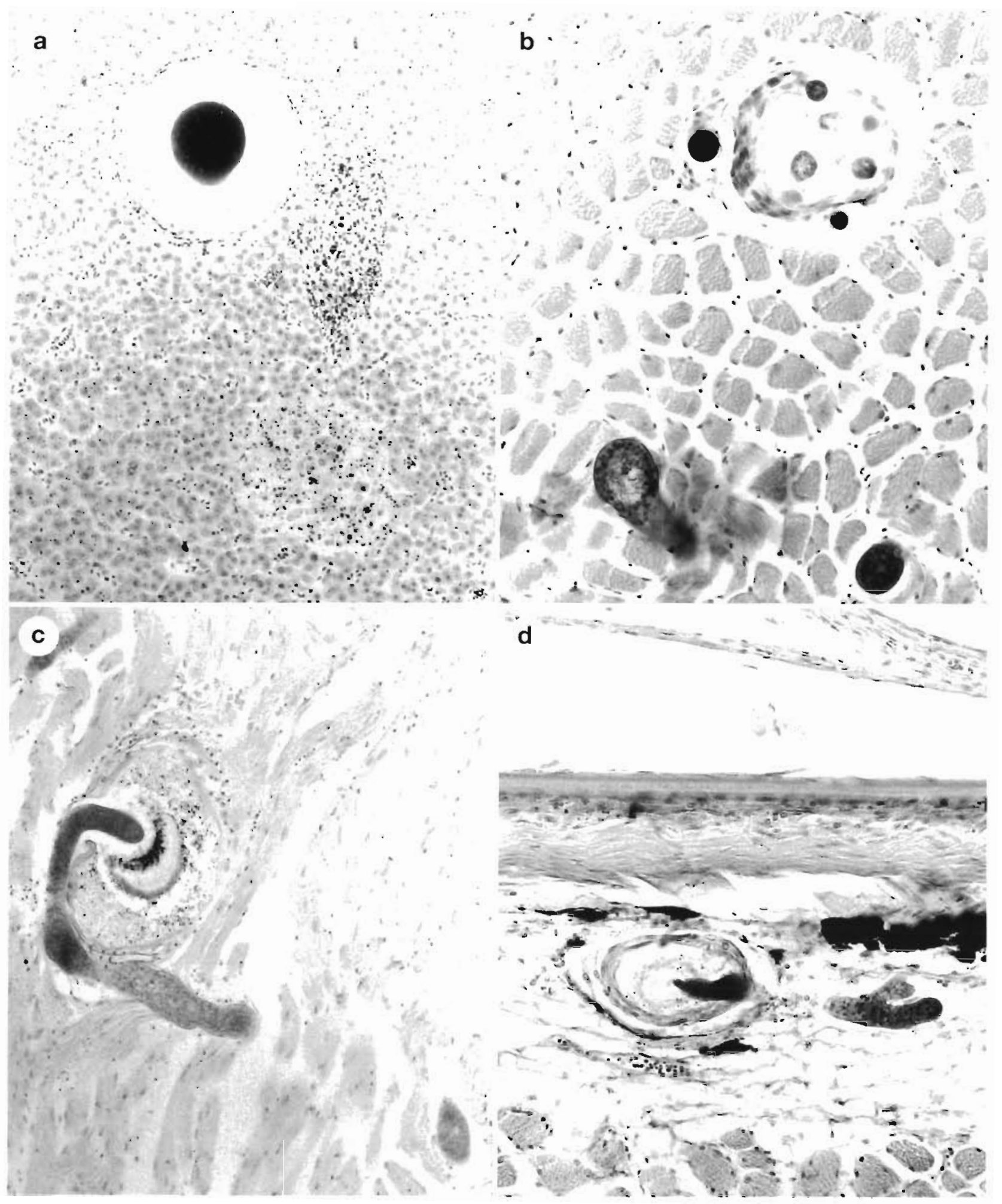

Fig. 5. Ichthyophonus sp. in Clupea pallasi tissues. (a) Liver: the resting spore of Ichthyophonus sp. is surrounded by a granuloma-like structure, which in turn is surrounded by compressed hepatocytes and inflammatory cells, generally non-pigmented, which can contain small dense granules. These areas are suggestive of $G$. clupearum in cardiac muscle of Pacific herring, 194×. (b) Muscle: resting spores of IChthyophonus in skeletal muscle of Pacific herring. In addition to the primary granuloma-like structure, additional fungal cells have become encysted at the periphery of the larger structure. Germinating hyphae in the absence of host tissue response are shown in the lower portion of the photomicrograph, $112 \times$. (c) Heart: the resting spore structure is surrounded by a thin, granuloma-like structure, and the germinating hypha is invasively growing through host muscle cells, $97 \times$. (d) Skin: germinating resting spore of Ichthyophonus sp. in sub-dermal connective tissue of Pacific herring. Epidermis and scales are shown in the upper portion of the photomicrograph, and skeletal muscle is shown in the lower portion. The resting spore is surrounded by a granuloma-like structure, which in turn is surrounded by a melanized layer, $100 \times$ 
In $8 \%$ of the fish livers examined, similar lightly stained areas were present, but there was no fibrosis associated with these lesions, and no infectious agents, including Goussia clupearum, were identified (Fig. 5A). A few enlarged hepatocytes with uniform round inclusion bodies and 2 nuclei per cell were occasionally observed in these areas (Fig. 4D).

Analysis of the $49 \%$ of the fish with Goussia clupearum infections revealed statistically significant variation in infection severity by location and sex. Statistically significant differences were not found by collection date or among predominant year classes. Fish in the 1990 year class exhibited Goussia sp. infections rated moderate to heavy in intensity, 30\% and $7 \%$, respectively, in fish from Port Chalmers and from Rocky Bay 2, in contrast to the low intensity Goussia sp. infections seen in the fish from Rocky Bay $1(57 \%)$ and Stockdale Harbor $(60 \%)$.

The male 1990 year class fish tended to have a higher prevalence $(p=0.06)$ and intensity $(p=0.13)$ of Goussia sp. infections than females of the same year class. The severity of the Goussia sp. infections among the male 1990 fish was significantly higher (ANOVA: $p=0.03, \mathrm{df}=42$ ) than among the female fish.

Prevalence, intensity and severity of Goussia sp. infections tended to decrease with increasing reproductive development in the 1990 year class fish, but the results were not statistically significant (1-way ANOVA: $\mathrm{p}=0.04$, $\mathrm{df}=43$; Tukey-Kramer not significant).

The CF of the fish with Goussia sp. infections was not significantly different (1-way ANOVA: $\mathrm{p}=0.28, \mathrm{df}=$ 133) than that of fish without these infections.

Ichthyophonus sp.: Evidence of the presence of Ichthyophonus $\mathrm{sp}$., a systemically distributed fungal parasite of Pacific herring, consisted of multifocal infections in heart, liver, kidney, skeletal muscle, gonad, gastro-intestinal tract and visceral connective tissue. Based on the descriptive terminology supplied by Lauckner (1984), we observed uni- and multinucleate cysts, as well as spores and resting spores, some of which were germinating into straight or branching hyphae. Host tissue response to Ichthyophonus sp. was uniform in various tissues and seemed related to the chronicity of the particular site of infection. Relatively small cysts and hyphae were observed with virtually no host response and were considered recent and active invasions of tissue. Larger cysts and resting spores were typically contained in a granuloma-like structure. In some cases, the external surface of the granuloma was distinctly melanized. In the heart, the granuloma-like structures tended to appear loose and separate from surrounding cardiac muscle. In liver, compression of surrounding hepatocytes resulted in an accumulation of dead and degenerating hepatocytes at the surface of the structure. The thickness of the granuloma-like structures and the degree of melanomacrophage infiltration and melanization was variable. The increased manifestation of all these features was interpreted to indicate a longer-term infection and host response.

The prevalence of Ichthyophonus sp. infections in all fish, in fish collected in mid-April and in fish collected in late April was $18 \%, 16 \%$ and $23 \%$, respectively (Table 8). Eight percent of the livers examined had multifocal infections of Ichthyophonus sp., and some of these infective foci were associated with melanomacrophage centers (MMCs). Ichthyophonus sp. infections were noted in the heart and conus arteriosus of $9 \%$ of the fish examined, and there wore multifocal fibrotic foci in the outer (dorsal) or underlying muscle layer of $7 \%$ of the fish examined, believed to result from chronic infestations with Ichthyophonus $\mathrm{sp}$. Chronic interstitial Ichthyophonus sp. infections were observed in $7 \%$ of the kidneys. Eleven percent of the fish examined had Ichthyophonus sp. infections in the connective tissue surrounding the digestive organs, and 1 of the 134 fish examined had Ichthyophonus sp. in the reproductive tract.

No statistically significant differences or trends were identified in Ichthyophonus sp. infection prevalence, intensity or severity in fish examined by collection site, collection date, year class, sex, or health and condition indices.

Ichthyophonus sp. and Goussia sp. and condition factor: The CF of the fish with both Ichthyophonus $\mathrm{sp}$. and Goussia sp. infections was not significantly different ( 1 -way ANOVA: $p=0.3, \mathrm{df}=133$ ) than that of fish without these infections.

No lesions. Necropsy and histological examination did not reveal lesions (excluding herring worms, Anasakis sp.) in $19 \%$ of 134 fish examined. No lesions were detected in $21 \%$ of the fish collected on April 12 and 13, nor in $14 \%$ of the fish collected on April 24 (Table 8).

\section{Numerical analysis of indices}

Liver hepatocellular vacuolation index. Statistical analysis of the hepatocellular vaculoation index (HCVI) revealed significant differences among location, collection date and reproductive stage. No significant differences were found among predominant year classes.

Sample location: The average HCVI of 4 yr old fish from Stockdale Harbor was significantly lower than that of the same age fish from Port Chalmers $(p=0.04$, $\left.\chi^{2}=8.3, \mathrm{~d} f=20\right)$ or from Rocky Bay $2\left(\mathrm{p}=0.02, \chi^{2}=\right.$ 10.38, df $=24$ ). 
Collection date: The average HCVI of the Rocky Bay 21990 year class fish was significantly higher than that of the fish from Rocky Bay $1\left(\mathrm{p}<0.01, \chi^{2}=12.1\right.$, $\mathrm{df}=21$ ).

Reproductive stage: The HCVI of the 1990 year class fish increased steadily as the fish progressed through the reproductive cycle $\left(p=0.037, \chi^{2}=13.4, \mathrm{df}=40\right)$. The fish that were developing or reproductively mature had a lower average HCVI than those that were spawned-out ( $p=0.01$ and $p=0.04$, respectively).

Liver melanomacrophage index. Aggregations of MMCs were observed in each of the 132 herring livers examined. The quantification of the MMCs, as measured in this study by the liver melanomacrophage index (LMMI), in livers examined from 97 fish collected in mid-April averaged 0.46 and ranged from 0.01 to 1.61 . The average LMMI of livers examined from 35 fish collected in late April was 0.70 and ranged from 0.04 to 1.81 . Statistically significant differences were found among the LMMIs of the herring by sample lacation, collection date and reproductive stage.

Sample location: The average LMMI of the 1990 year class fish was significantly higher at Rocky Bay 2 than at Port Chalmers (1-way ANOVA: $\mathrm{p}=0.001, \mathrm{df}=$ 43; Tukey-Kramer HSD $=0.22$ ) .

Collection date: The average LMMI of the 1990 year class fish was significantly higher at Rocky Bay 2 than at Rocky Bay 1 (1-way ANOVA: $p=0.001, \mathrm{df}=43$; Tukey-Kramer HSD $=0.08$ )

Reproductive stage: The trend of the average LMMI of the 1990 year class fish was toward higher LMMI with advancing reproductive stage, but the results were not statistically significant (1-way ANOVA: $p=$ $0.10, \mathrm{df}=42$ ).

\section{DISCUSSION}

\section{Fin and skin lesions}

Fin and skin lesions observed at necropsy may result from infection or abrasions occurring during spawning behavior and capture. Such lesions can result from VHSV infection, and if the infection is progressive, ulceration of the skin will disrupt the fishes' ability to osmoregulate and can lead to death (Meyers et al. 1994). Although some herring in this study had fin and skin lesions, no evidence of viral or bacterial infection was found. The most likely explanation is that these lesions resulted from spawning behavior and crowding.

VHSV can apparently initiate or exacerbate the observed fin and skin lesions in herring. Meyers et al. (1994) believe that herring are a reservoir for VHSV, and when VHSV is present at a significant level, fin and skin lesions initiated by spawning behavior would be amplified by the virus. Historical information on lesion prevalence resulting from VHSV is lacking because the disease was not recorded in Pacific herring before 1993. However, in another study of PWS herring in 1994, Marty et al. (1995) reported the isolation of VHSV in $4.7 \%(11 / 233)$ of the fish examined from Rocky Bay between April 21 and 26, 1994, indicating a relatively low prevalence of isolatable virus in fish sampled late in the spawning season.

In this study, the prevalence of fin and skin lesions in all fish did not vary significantly with sampling date, but when the analysis was constrained to a single year class (1990) and all 4 collections were examined, significant differences in prevalence occurred by geographic location and over time (by collection date) at the same location. The increase in lesions over time was likely related to increased spawning concentration of fish and resulting stress, since a relatively large proportion of the fish in the second Rocky Bay sample was spawned out. The increase in skin lesions in the fish from the Port Chalmers location relative to Stockdale Harbor and Rocky Bay 1 is apparently not related to reproductive condition and demonstrates the degree of variability within herring of the same age class spawning at different sites. The intensity of skin and fin lesions observed in this study ranged from mild to moderate and were not correlated with the $\mathrm{CF}$ of the fish. This supports the hypothesis that the lesions are associated with recent events, such as spawningrelated behavior.

\section{Viral erythrocyctic necrosis}

Our examination of herring blood preparations did not reveal intracytoplasmic inclusion bodies consistent with VEN (Meyers et al. 1986). VEN has been described as widespread and chronic in marine fishes (Sinderman 1990), and Meyers et al. (1986) have previously described VEN in association with juvenile herring mortalities in Alaska. Meyers et al. (1994) also indicated that under environmentally stressful conditions, mortality from VEN can occur.

\section{Ichthyophonus sp.}

The presence of the cosmopolitan fungus, Ichthyophonus sp., is well documented in at least 80 species of fish, with reported prevalence from $2 \%$ to $100 \%$. Effects of the fungus infection range from minimal (e.g. in mackerel and cod) to severe, and epizootics can be associated with stock reductions (e.g. in Atlantic herring) (Lauckner 1984, Sinderman 1990). The report of 
Marty et al. (1995) contains a detailed description of the infection in PWS herring. In those studies, and a subsequent one (Marty et al. 1996), prevalence of Ichthyophonus in spawning PWS herring is reported at $29 \%$ and $22.3 \%$, respectively, in 1994 and 1995, while only $6.2 \%$ prevalence was reported in prespawning PWS herring in 1995. These data are consistent with our results that show an increase of of Ichthyophonus prevalence over an approximate 2 wk period suggesting that the parasite may rapidly colonize spawning fish.

The systemic nature of Ichthyophonus sp. infection and the elevated prevalence of focal infections in wellvascularized organs and tissues of the herring in this study are consistent with published reports of Atlantic herring infections (Amlacher 1970, Sinderman 1990). In our study, the prevalence of Ichthyophonus sp. infections was about $20 \%$; however, the severity of infection was low in comparison with that described in Atlantic herring. For example, the severity scale of 1 to 8 for heart infections depicted by Sinderman (1990) indicates that our observation at necropsy would result in a rating of less than 1 for the most severely infected organ observed (heart).

Our results indicate that Ichthyophonus sp. is a significant pathogen in Pacific herring, capable of producing moderate to heavy infections, although the time course and potential for resolution of such infections is unknown. It is reasonable to assume that infections rated as heavy and occurring in several organs are fatal, but the lack of experimental studies and more historical data, which would help assess the time course and outcome of this disease, prohibits assessment of the numerical impact to PWS herring populations. In this study, there was no statistically significant relationship of Ichthyophonus sp. infection with herring age, condition index or any other variable. Thus, there is no evidence for a differential year class expression of the fungus or a differential year class susceptibility of herring to the infection.

\section{Goussia sp.}

The protozoan Goussia clupearum (formerly Eimeria) is a previously reported parasite of Pacific herring (Moles 1982) which occurs primarily in the liver. Although the prevalence of the protozoan in this study was approximately $50 \%$, this parasite has not been considered a serious pathogen (Sinderman 1990, Costa \& MacKenzie 1994). In our herring with the heaviest liver infections, histological evaluation revealed minimal to moderate host response to the pathogen, although liver function could have been affected through displacement of liver tissue by large numbers of oocysts (Dykova \& Lom 1981, Overstreet et al. 1984, Costa \& MacKenzie 1994).

The prevalence of Goussia sp. infections did not vary with collection date. However, when herring of the 1990 year class were considered, fish from 2 of the 3 collection sites (PC and RB2) had infection levels rated as moderate and heavy. This greater severity parallels the pattern of greater skin and fin lesions for these 2 sample groups.

The Goussia sp. infections in the male fish of the 1990 year class varied by location, tended to be of a higher prevalence and intensity, and to be significantly more severe than those in the female fish. Although the impact of Goussia sp. infections of Pacific herring remains largely unknown, sex effects could influence the success of herring reproduction. The Goussia sp. infection prevalence tended to increase with reproductive development in the Rocky Bay 2 sample.

Thirteen percent of the livers examined had multifocal areas of hepatocyte necrosis and macrophage infiltration, but no evidence of infectious agents could be identified. The appearance of these foci was very similar to the foci of Goussia sp. infection. We believe that they represent foci of early or resolving Goussia sp. infections, or those in which the parasite was not intersected in the section. The high prevalence of Goussia $\mathrm{sp}$. infection in the samples is consistent with this interpretation.

Age distribution, length, weight and condition factor

Age distribution of herring varied with location and collection date (Fig. 3). The Port Chalmers fish, with a greater prevalence of skin lesions and Goussia infections, were dominated by young fish $(<4$ yr old). The fish from Stockdale Harbor showed a bi-modal pattern, dominated by 4 and 6 yr old fish. The fish sampled from Rocky Bay 1 were predominantly 5 and $6 \mathrm{yr}$ old. The samples collected later in the spawning cycle from Rocky Bay 2 were no longer dominated by 5 and 6 yr old fish, but rather by younger, 4 and 5 yr old fish.

The age of herring affects measured parameters of health, growth, reproduction, behavior of the fish and liver MMCs (Ferguson 1989); therefore, we partitioned and evaluated the data by age class. The substantial differences in age class structure among the samples examined in this study show that age must be taken into account when performing a fish health and condition evaluation.

We used standard fisheries indices, consisting of fish length, weight and the relationship between weight and length (CF), in order to evaluate the condition of herring stocks. The trend of increased 
weight, length and CF with age for all herring in this study indicated that as the fish aged they increased in length and gained more body weight, and that the relationship between length and weight (CF) remained relatively constant. However, the data also demonstrated that there was significant variation in these parameters among fish populations by sample location, collection date and year class. For example, the 4 yr old fish collected from Port Chalmers in midApril were shorter, weighed significantly less and had a significantly lower CF than the 4 yr old fish from the other 2 sites sampled on the same date. These observations demonstrate that unless variations in fish populations related to sample location, collection date and year class are taken into account misinterpretation of data is likely.

\section{Liver hepatocellular vacuolation index}

The HCVI is used as an indicator of liver metabolism and lipid presence or accumulation in the livers of herring. In this study, the HCVI of the herring we examined increased as the fish progressed through the reproductive cycle. It was significantly lower in fish during early stages of gonadal development, increased as fish developed mature gametes, and was significantly higher in fish that had successfully spawned.

After the 'Amoco Cadiz' oil spill in France in 1978, differences over time (collection date) in overall means of HCVI measurements of fish sampled from locations exposed or unexposed to oil were interpreted as an indication of negative oil spill impacts (Haensly et al. 1982). These results included significant variation with collection date and location, with small differences in mean HCVI observed from exposed and unexposed sites sampled during the same month. Our results indicated that such interpretations of HCVI differences to indicate negative oil spill impacts are invalid unless other factors associated with variation in this parameter, such as stage of reproductive development, are taken into account.

\section{Liver melanomacrophage index}

The LMMI also appears to be related to stage of reproductive development. Four yr old fish tended to have a higher LMMI as their stage of reproductive development progressed, and it varied significantly with collection date and location. The 4 yr old fish from Rocky Bay 2 had a higher LMMI than fish collected earlier from the same site (RB1), and from Stockdale Harbor.
MMCs, as measured in this study by the LMMI, are believed to represent, in at least some cases, a measure of host response and stress, including exposure to pollutants. Agius (1985) reviewed literature pertaining to piscine MMCs and concluded that, since these structures are involved in various disease processes and exhibit changes due to factors such as starvation, they could provide sensitive indicators of stressful conditions in the aquatic environment. MMCs occur in the liver, spleen, kidney interstitium, and some other tissues of most teleost fishes; they are believed to appear in fish that have been starved and to increase in number and size as fish age (Ferguson 1989). Although MMCs can be regarded as indicators of host response and stress, their occurrence can be inconsistent with respect to specific disease conditions; further, the induction of MMCs and dose-response to particular contaminants or contaminant mixtures has not been determined. This study indicates that MMC concentration in the liver of herring can vary significantly in fish collected in close proximity and over a short time interval and that MMC intensity can vary depending on the reproductive stage of development. Thus, although MMCs can be a marker of exposure to pollutants or of other forms of stress, unless other significant shortterm factors associated with MMC occurrence and intensity are determined and taken into account, they cannot be used reliably as indicators of pollutant exposure.

\section{Condition of Port Chalmers and Rocky Bay 2 fish}

A variety of indices showed that the health and condition index of the fish from the Port Chalmers and Rocky Bay 2 samples was significantly lower than that of fish from Stockdale Harbor and Rocky Bay 1. For example, fish from the former 2 collections had a greater prevalence and intensity of skin and fin lesions, greater prevalence of Goussia sp. and lower average weight and $C F$ than fish from the other collections. Fish from Port Chalmers were shorter than fish from other samples. The Rocky Bay 2 fish were similar in average length, had higher HCVIs and LMMIs and were more reproductively advanced, on average, than fish from the 3 earlier collections.

These indices of poorer condition of the Rocky Bay 2 fish could be reasonably attributed to the more advanced reproductive development and spawning status of the herring. The cause for poorer condition of the Port Chalmers fish is not clear, but these fish could represent a stock of herring with poorer nutritional history than the fish from the other samples (Pearson et al. 1996). However, the nutritional history of these fish is not known. 


\section{Hypotheses addressing low herring returns}

A variety of life history stress factors, such as exogenous chemicals, behavioral experiences, nutritional insufficiencies, infectious diseases and environmental contaminants, can result in immunosuppressive effects in fish or in the alteration of in vitro measures of immunity.

With respect to the effects of petroleum hydrocarbons on the immune response of fish, particularly on salmon and herring, the scientific literature is extremely limited. Arkoosh et al. (1994) showed that juvenile salmon injected with $0.6 \mathrm{mg}$ DMBA per $\mathrm{kg}$ of fish weight could show a decrease in some, but not all specific in vitro assays of immune system function. Faisel \& Huggett (1993) showed that concentrations of $10^{-8}$ to $10^{-15} \mathrm{M}$ of the pyrogenic (from burned fossil fuels) PAH, benzo-a-pyrene (BP) or certain BP metabolites injected into a fish could reduce the in vitro capacity of the fish leukocytes to kill tumor cells from a cell line. Both of these studies demonstrated potential mechanisms by which BP could affect the immune response of fish, but neither study defined the dose and duration of exposure to PAHs from crude oil needed in the environment to produce the demonstrated effect. Once a dose-response relationship is defined, the significance of alterations of these specific in vitro measures of immune response to the ability of fish to maintain health needs to be determined by in vivo challenge tests with pathogens or by other appropriate means.

One of the key problems with field studies that show a compromised immune response from fish in contaminated areas is that the type, dose and duration of exposure are unknown or incompletely known. Nonetheless, field studies have shown a depressed immune response in fish with PAHs in tissues, although the exposure history of the fish is unknown (Arkoosh et al. 1991, 1994). Although a reasonable case for associating some level of PAH exposure with depressed immunity in fish exists, a dose-response relationship has not been determined.

Brown et al. (1994) advanced the hypothesis that the expression of VHS virus in PWS herring in 1993 was the result of an immunosuppressive effect of the 'Exxon Valdez' oil spill in PWS in 1989. This hypothesis is apparently based on the assumption that 1989 year class herring resident in PWS in 1989 were affected by toxic components of the spilled oil, and that this toxicity manifested itself in a delayed immunosuppressive effect. According to this hypothesis, the delayed immunosuppressive effect did not become evident until these herring returned to PWS in 1993 to spawn, and further, the delayed immunosuppressive effect allowed VHS virus to proliferate among the herring population and to spread to other year classes of herring in 1993.

Several points cast doubt on the hypothesis that exposure of PWS herring to toxic petroleum hydrocarbons from the 1989 'Exxon Valdez' spill resulted in immunosuppressive effects in 1994. First, an immunosuppressive effect would be expected to manifest itself throughout the life cycle of the herring. It is reasonable to assume that this effect would occur within a matter of days to weeks after the spill and that affected fish would be progressively subject to infections of increasing intensity from a variety of infectious agents known to occur in PWS herring. Although the progression of the fish into spawning condition 4 yr after the potential exposure to toxic petroleum hydrocarbons would be a stressful event, it is unlikely that immunosuppressed fish would survive the rigors of their maturation for the 4 yr prior to spawning.

An immunosuppressive effect would allow the nonselective proliferation of a variety of parasites and infectious agents carried by the herring, such as conditons documented historically (Moles 1982, Meyers et al. 1986), those described in this study and the Marty et al. $(1995,1996)$ reports as well as other opportunistic infectious agents present in the environment. If immunosuppressed fish carrying infectious agents were removed from the population by a fatal disease outcome, one might assume that the surviving fish of that year class would have a lower prevalence and intensity of disease. Alternatively, it might be argued that the affected year class would suffer a higher chronic prevalence of specific diseases. However, as shown in this study, there were no significant differences in the prevalence or intensity of infectious diseases by age.

The concept that there would be a selective immunosuppression in relation to VHSV is also without support. PWS herring are known to be infected with a variety of pathogens and parasites that should have increased markedly in the herring, if the episode of VHS disease were due to immunosuppression. The recognition of VHS in PWS herring populations in 1993, and not before, most likely reflects the lack of previous effort to detect the virus, which Meyers et al. (1994) hypothesized has likely been present historically in Alaskan herring populations. Marty et al. (1995, 1996), who also studied herring diseases in PWS, conclude that hydrocarbon exposure to yearling herring in 1989 did not result in permanent immune suppression and subsequent disease outbreaks.

An alternative to the immunosuppression hypothesis is that poor nutritional condition of herring, coupled with cold winter temperatures and possibly a cyclical density-dependent downturn in population numbers, could have led to the collapse of the PWS herring population. Specific dietary deficiencies and inadequate 
protein and caloric intake in the diet can have a profoundly depressing effect on the immune response. A low-protein diet resulted in reduced resistance to disease in an experimental application (Hardy et al. 1979); this finding would apply to fish in the natural environment, where dietary intake and various degrees of starvation and other environmental stressors would exacerbate the problem. The possibility that dietary insufficiency in PWS herring is a result of reduced food availability is discussed in more detail by Pearson et al. (1997) along with other hypotheses related to low herring returns in 1993 and 1994.

The data we analyzed were insufficient to definitively determine the cause of low herring returns in 1993 and 1994. Historical data collected on the herring fishery by other investigators offer some insight into the trend toward poor herring condition in PWS. The cyclic nature of fish weight at age is described by Brown et al. (1994), who also demonstrated a progressively lower weight at age of PWS herring beginning in 1987. In addition, Pearson et al. (1997) reviewed data that show the decreasing weight gain of PWS herring between the fall and spring fisheries starting in 1985. Thus, there have been indications of either a cyclic or a long-term trend toward poor condition of herring in PWS since the mid-1980s, suggesting that factors predating the 'Exxon Valdez' oil spill are responsible for the poor condition of the fish. Alternatively, Marty et al. (1996), assuming that all fish infected with Ichthyophonus or VHSV in April 1994 died, conclude that these diseases are sufficient to explain the declines in PWS herring between April and October 1994. We believe that these diseases may be more accurately viewed as consequences of larger scale ecological changes that have resulted in reduced food availability for the herring.

This study has for the first time quantitatively defined the variability of health and condition indices of Pacific herring in relation to age, collection date and location of herring collections. It demonstrates the essential need to account for age, reproductive status, collection date and location of samples to make valid use of health and condition measurements of herring. Variation in age structure within groups sampled at different locations at the same date and at different dates must be statistically accounted for in the interpretation of health and condition indices. Failure to do so may result in invalid hypotheses, misinterpretations and faulty conclusions. If measurements from collections that vary spatially and temporally are pooled and used to develop baseline health and condition information, imprecise data of limited use would likely result. Furthermore, the relationships and variability demonstrated in this study show that without baseline information it is impossible to form meaningful hypotheses and to draw valid conclusions from herring health and condition data.

This study revealed no trends in herring health and condition in 1994 that could reasonably be attributed to the 'Exxon Valdez' spill in 1989. More importantly, perhaps, from a fisheries management perspective, is the demonstration that attempts to make such linkages based on herring health and condition 4 and 5 yr after an oil spill without a full understanding of herring population ecology are extremely tenuous. Our results point to the need for a better understanding of spawning behavior and spawning site fidelity. Studies of the mechanistic relationships between health and condition parameters and physiology, behavior, pathogen load, mode of transmission and other fundamental features of herring biology are essential before definitive conclusions of disease effects on the herring population can be drawn.

Acknowledgements. This study was funded under a contract from the Exxon Corporation. The assistance of Ross Hibler, Dave Shreffler and Marilyn Wilkinson for technical support, and Susan Thomas and Marilyn Wilkinson for editing is gratefully acknowledged.

\section{LITERATURE CITED}

Agius C (1985) The melano-macrophage centers of fish: a review. In: Fish immunology. Academic Press Inc, London, p 85-105

Amlacher E (1970) Textbook of fish diseases. TFH Publications, Neptune, NJ

Arkoosh MR, Casilla E, Clemons E, McCain B, Varanasi U (1991) Suppression of immunological memory in juvenile chinook salmon (Oncorhynchus tshawytscha) from an urban estuary. Fish \& Shellfish Immunol 1:261-277

Arkoosh MR, Stein JE, Casillas E (1994) lmmunotoxicology of an anadromous fish: field and laboratory studies of b-cell mediated immunity. In: Stolen JS, Fletcher TC (eds) Modulators of fish immune responses, Vol 1, Chap 4. Fair Haven, NJ, p 33-48

Bienert RW (1994) 1994 aerial survey of Pacific herring spawning in Prince William Sound, Alaska. Prepared for Exxon Company by Battelle Marine Sciences Laboratory, Pacific Northwest Laboratories, Richland, Washington

Bienert RW, Pearson WH (1993) Distribution of Pacific herring spawning in Prince William Sound: an historical overview and results of an intensive survey conducted one year following the Exxon Valdez spill. Presented at AFS Annual Meeting, Portland, Oregon, September 1993

Brady J, Morstad S, Simpson E, Biggs ED (1991) Prince William Sound management area 1990 annual finfish management report. Reg info rept 2C91-14, Dept Fish \& Game, Anchorage

Brown ED, Baker TT, Funk F, Hose JE, Kocan RM, Marty GD, McGurk MD, Norcross BL, Short JW (1994) The Exxon Valdez oil spill and Pacific herring in Prince William Sound, Alaska: a summary of injury from 1989-1994. In: Brown ED, Baker TT (eds) Injury to Prince William Sound following the Exxon Valdez oil spill: final report for fish/ shellfish study number 11. Alaska Dept Fish \& Game, Div Comm Fisheries Mgt \& Devel, Anchorage 
Cohen J (1988) Statistical power analysis. Lawrence Erlbaum Associates. Hillsdale, $\mathrm{N} J$

Costa G, Mackenzie K (1994) Histopathology of Coussia clupearum (Protozoa: Apicomplexa: Coccidia) in some marine fish from Scottish waters. Dis Aquat Org 20:195-202

Dykova I, Lom J (1981) Fish coccidia: critical notes on life cycles, classification and pathogenicity. J Fish Dis 4: $487-505$

Faisel M, Huggett RJ (1993) Effects of polycyclonic aromatic hydrocarbons on the lymphocyte mitogenic responses in spot (Leiostromus xanthurus). Mar Environ Res 35: 121-124

Ferguson HW (1989) Systemic pathology of fish. Iowa State University Press

Fienberg SE (1980) The analysis of cross-classified categorical data. MIT Press, Cambridge, MA

Haensly WE, Neff JM, Sharp JR, Morris AC, Bedgood MF, Boehm PD (1982) Histopathology of Pleuronectes platessa L from Aber Wrac'h and Aber Benoit, Brittany, France: long term effects of the Amoco Cadiz crude oil spill. J Fish Dis 5:365-391

Hardy RW, Halver JE, Brannon EL (1979) Effect of dietary protein level on the pyridoxine requirement and disease resistance of chinook salmon. College of Fisheries, UW, Seattle

Lauckner G (1984) Diseases caused by microorganisms; Agents: fungi. In: Kinne $O$ (ed) Diseases of marine animals, Vol 4, Part 1, Introduction, Pisces. Biologische Anstalt Helgoland, Hamburg, p 89-113

Luna LG (1968) Manual of histologic staining methods of the Armed Forces Institute of Pathology. McGraw-Hill Book Co., New York

Marty GD, Davis CR, Freiberg EF, Hinton DE, Meyers TR, Wilcock J (1996) Causes of morbidity in Pacific herring from Sitka Sound and Prince William Sound, Alaska, in spring 1995. Exxon Valdez Oil Spill, Restoration Project Annual Report. Restoration Project 95320S, Section I Filed Component, Annual Report April 1996

Marty GD, Freiberg EF, Meyers TR, Wilcock JA, Davis CR, Farver TB, Hinton DE (1995) Ichthyophonus hoferi, viral hemorrhagic septicemia virus, and other causes of morbidity in Pacific herring spawning in Prince William Sound in 1994. Exxon Valdez Oil Spill, Restoration Project Annual Report. Restoration Project 94320S, Annual Report June 1995

Editorial responsibility: Carl Schreck,

Corvallis, Oregon, USA
Meyers TM, Hauck AK, Blankenbeckler WD, Minicucci $T$ (1986) First report of viral erythrocytic necrosis in Alaska, USA, associated with epizootic mortality in Pacific herring, Clupea harengus pallasi (Valenciennes). J Fish Dis $9: 479-491$

Meyers TR, Short S, Lipson K, Batts WN, Winton JR, Wilcock $J$, Brown E (1994) Association of viral hemorrhagic septicemia virus with epizootic hemorrhages of the skin in Pacific herring Clupea harengus pallasi from Prince William Sound and Kodiak Island, Alaska, USA. Dis Aquat Org 19:27-37

Meyers TR, Sullivan J, Emmenegger E, Follet J, Short S, Batts WN, Winton JR (1992) Identification of viral hemorrhagic septicemia virus isolated from Pacific cod Gadus macrocephalus in Prince William Sound, Alaska. Dis Aquat Org 12:176-175

Moles A (1982) Parasite host records of Alaskan fishes NMFS-SSRF-760, National Oceanic and Atmospheric Administration Tech Rpt, Washington, DC

Neff JM, Owens EH, Stoker SW, McCormick DM (1995) Shoreline oiling conditions in Prince William Sound following the Exxon Valdez oil spill. In: Wells PG, Butler JN, Hughes JS (eds) Exxon Valdez oil spill: fate and effects in Alaska waters, STP 1219. ASTM, Philadelphia, p 312-346

Overstreet RM, Hawkins WE, Fournie JW (1984) The coccidian genus Calyptospora $\mathrm{n}$. g. and family Calyptosporidae n. fam. (Apicomplexa), with members infecting primarily fishes. J Protozool 31:332-339

Pearson WR, Elston RA, Bienert RW, Drum AS, Antrim LD (1997) Why did the Prince William Sound, Alaska, herring fisheries collapse in 1993 and 1994? Review of hypotheses Can J Fish Aquat Sci (in press)

Pearson WR, Moksness E, Skalski JR (1995) A field and laboratory assessment of oil spill effects on survival and reproduction of Pacific herring following the Exxon Valdez spill. In: Wells PG, Butler JN, Hughes JS (eds) Exxon Valdez oil spill: fate and effects in Alaska waters, STP 1219. ASTM, Philadelphia, p 626-661

Sinderman CJ (1990) Principal diseases of marine fish and shellfish: diseases of marine fish, Vol 1, 2nd edn. Academic Press, Inc, San Diego, California

Thoesen JC (ed) (1994) Suggested procedures for the detection and identification of certain finfish and shellfish pathogens, 4th edn, Vers 1. Fish Health Sect, Am Fisheries Soc, Bethesda, MD

Submitted: February 22, 1996; Accepted: August 7, 1997

Proofs received from author(s): October 14, 1997 